American Journal of Environmental Sciences 5 (1): 33-40, 2009

ISSN $1553-345 \mathrm{X}$

(C) 2009 Science Publications

\title{
Improvement of Biohydrogen Production under Increased the Reactor Size by C. acetobutylicum NCIMB 13357
}

\author{
${ }^{1}$ Hisham Salem Alshiyab, ${ }^{2}$ Mohd Sahaid Kalil, ${ }^{1}$ Aidil Abdul Hamid and ${ }^{1}$ Wan Mohtar Wan Yusoff \\ ${ }^{1}$ Faculty of Science and Technology, School of Bioscience and Biotechnology \\ ${ }^{2}$ Department of Chemical and Process Engineering Faculty of Engineering, \\ University Kebangsaan Malaysia, 43600 UKM Bangi Selangor, Malaysia
}

\begin{abstract}
Problem statement: One of the main factors influenced the bacterial productivity and total yield of hydrogen is the partial pressure of produced gas. A novel solution to enhance the bacterial productivity was through reduction of gas pressure. Approach: Increasing the reactor size showed to enhance the bacterial production of hydrogen. Results: The technique of increasing reactor size resulted to enhance the hydrogen yield $\left(\mathrm{Y}_{\mathrm{P} / \mathrm{S}}\right)$ from $269 \mathrm{~mL} \mathrm{~g}^{-1}$ glucose utilized to maximum yield of $448 \mathrm{~mL} \mathrm{~g}^{-1}$ glucose utilized by using $125 \mathrm{~mL}$ and $2 \mathrm{~L}$ reactor size respectively. The hydrogen productivity was also enhanced from $71 \mathrm{~mL}^{-1} \mathrm{~h}^{-1}$ to maximum of $91 \mathrm{~mL} \mathrm{~L}^{-1} \mathrm{~h}^{-1}$ was obtained by using $125 \mathrm{~mL}$ and $1 \mathrm{~L}$ reactor size respectively. Biomass concentration was enhanced from $1.03 \mathrm{~g} \mathrm{~L}^{-1}$ to maximum of $1.68 \mathrm{~g} \mathrm{~L}^{-1}$ by using $125 \mathrm{~mL}$ and $2 \mathrm{~L}$ reactor size were used respectively, hydrogen yield per biomass $\left(\mathrm{Y}_{\mathrm{P} / \mathrm{X}}\right)$ of $267 \mathrm{~mL} \mathrm{~g}^{-1} \mathrm{~L}^{-1}$, biomass per substrate utilized $\left(\mathrm{Y}_{\mathrm{X} / \mathrm{S}}\right)$ of 0.336 and produced hydrogen in gram per gram of glucose utilized $\left(\mathrm{Y}_{\mathrm{H} 2 / \mathrm{s}}\right)$ of 0.04 when $2 \mathrm{~L}$ reactor size was employed. Conclusion: By using bigger reactor size, the effect of gaseous products in fermentation medium was reduced and enhanced both bacterial productivity and biomass concentration.
\end{abstract}

Key words: Biohydrogen, C. acetobutylicum, glucose, reactor size

\section{INTRODUCTION}

Major advantages of fermentative $\mathrm{H}_{2}$ production processes are higher evolution rate of $\mathrm{H}_{2}$ and a wide gamut of substrate utilization. However, the inherent disadvantage of these processes is lower yield of $\mathrm{H}_{2}$. This is one of the major deterrents of the fermentative $\mathrm{H}_{2}$ production process. At most a maximum of $4 \mathrm{~mol}$ $\mathrm{H}_{2}$ could be obtained per mol glucose during acetate fermentation. To address this problem, efforts are needed to improve the operating conditions to overcome thermodynamic limitations ${ }^{1]}$ of the acetate fermentation reaction represented:

$$
\mathrm{C}_{6} \mathrm{H}_{12} \mathrm{O}_{6}+2 \mathrm{H}_{2} \mathrm{O} \rightarrow 2 \mathrm{CH}_{3} \mathrm{COOH}+2 \mathrm{CO}_{2}+4 \mathrm{H}_{2}
$$

Decrease of $\mathrm{H}_{2}$ partial pressure could be considered as an approach towards improvement of $\mathrm{H}_{2}$ productivity ${ }^{[2]}$. Equilibrium constant of the above reaction is According to Le Chatelier's principle; the equilibrium of the above reaction will shift to the right if one or both of the gaseous products of the reaction is removed. Decrease in partial pressure of $\mathrm{H}_{2}$ by reducing total pressure of the system allows the reaction equilibrium to shift towards right side and thereby enhance the $\mathrm{H}_{2}$ production.
In general, biological $\mathrm{H}_{2}$ production from organic substrates is limited by the thermodynamics of the hydrogenase reaction, involving the enzyme-catalyzed transfer of electrons from an intracellular electron carrier molecule to protons. On the contrary, protons are poor electron acceptors $\left(\mathrm{E} \mathrm{H}_{2}=-414 \mathrm{mV}\right)$ so, the electron donor must be a strong electron reducing agent. Ferredoxin is a low-potential $(\mathrm{E} \mathrm{Fd}=-400 \mathrm{mV})$ iron-sulfur containing protein that is capable of reducing proton to $\mathrm{H}_{2}$. Another important intracellular electron carrier, NADH, has a higher redox potential (E $\mathrm{NADH}=-320 \mathrm{mV}$ ). Under actual conditions the ability of reduced ferredoxin and NADH to reduce protons is determined by the redox potential of the overall reaction.

Fabiano et al. ${ }^{[1]}$ stated that, assuming the intracellular concentrations of the oxidized and reduced form of ferredoxin and NADH are equal, $\mathrm{H}_{2}$ production becomes thermodynamically unfavorable at high $\mathrm{H}_{2}$ partial pressure, this correlation indicates that for ferredoxin, $\mathrm{H}_{2}$ production can continue as long as the partial pressure of $\mathrm{H}_{2}$ is less than $0.3 \mathrm{~atm}$, while for $\mathrm{NADH}$, the partial pressure of $\mathrm{H}_{2}$ must be less than 60 Pas. This implies that at a very low partial pressure $<60 \mathrm{~Pa}$, NADH could also be used for $\mathrm{H} 2$ production. 
The present investigation shows, for the first time, that the reduction of pressure of produced gas by increasing the surface area of the reactor substantially improves $\mathrm{H}_{2}$ production in an anaerobic fermentation process. The $\mathrm{H}_{2}$ (yield and bacterial productivity), biomass growth and lag phase for gas production under different reactor size are reported.

\section{MATERIALS AND METHODS}

Microorganism and culture conditions: $C$. acetobutylicum NCIMB 13357 was purchased from a British culture collection, NCIMB Ltd. Scotland, UK. The bacterium was cultivated in anaerobic condition in Reinforced Clostridial Medium (RCM) for $24 \mathrm{~h}$ at $30^{\circ} \mathrm{C}$. Liquid medium of RCM was used for inoculum preparation. The growth of culture in RCM was monitored by measuring an optical density at $600 \mathrm{~nm}$ using a spectrophotometer. Only inoculum with Optical Density (OD) values greater than 0.4-0.6 after $18 \mathrm{~h}$ cultivation was used as inoculum. An inoculum of $10 \%$ $\mathrm{v} / \mathrm{v}$ was used throughout this study.

Cultivation medium: New medium we formulated in our lab to be used for hydrogen production and for the bacterium species we used in this study have the following composition in $\mathrm{g} \mathrm{L}^{-1}$ : Glucose (5), yeast extract (5), L-Cystine. $\mathrm{HCl}$ (1.0), bacteriological agar 0.5 and $\mathrm{FeSO}_{4} .7 \mathrm{H}_{2} \mathrm{O}(0.025)$. The initial anaerobic condition in the reactor after inoculation inside the anaerobic glove box was established by replacing the gaseous phase with nitrogen at start of cultivation. Then incubated at $30^{\circ} \mathrm{C}$ in temperature controlled water bath without shaking. The evolved gas was monitored and collected in a gas collection cylinder and the volume of evolved gas was measured at room temperature by the water displacement method $^{[3]}$ in a graduated cylinder inverted, that had been filled with water of $\mathrm{pH} 3$ or less in order to prevent dissolution of the gas components.

Analytical methods: The gas composition was determined by gas chromatography (Shimadzu Co., Kyoto, GC-8A) under the following conditions: column: Porapack-Q, carrier gas: Nitrogen, flow rate: $33 \mathrm{~mL} \mathrm{~min}^{-1}$ column temperature: $50^{\circ} \mathrm{C}$, injection temperature: $100^{\circ} \mathrm{C}$, detector temperature: $50^{\circ} \mathrm{C}$, detector: Thermal Conductivity Detector (TCD). The soluble glucose concentration was measured at the end of each batch experiment for the calculation of the amount of glucose consumed by DNS method modified by $^{[4]}$ using spectrophotometer (UV 1601IPC, Shimadzu corporation-Japan) Optical Density $\left(\mathrm{OD}_{550 \mathrm{~nm}}\right)$. Individual batch experiments were observed until the hydrogen production from each bottle stopped. All of these data were the average (mean) of three trials.

Experimental procedure: Five different bottles size ranging from 125-2000 mL, Scott bottle (Duran bottle as a reactor), were used to study the effect of the reactor size on hydrogen production by $C$. acetobutylicum NCIMB13357. Water manometer was used to measure the pressure of produced gas and was fixed to measure the pressure in the headspace (outlet tube). Measured gas pressure indicated that the maximum pressure that gas can produce. All of these data were the average (mean) of three trials. Plastic bag used for gas collection to be analyzed by GC for gas composition analysis.

\section{RESULTS}

It was noted that investigators have reported $\mathrm{H}_{2}$ yield as $\mathrm{mol}_{2}$ per mol substrate, mol $\mathrm{H}_{2}$ per gram substrate or $\mathrm{H}_{2}$ produced $(\mathrm{mL})$ per gram substrate; hence, for ease of comparison with values reported, the $\mathrm{H}_{2}$ yields were all converted to $\mathrm{H}_{2}$ produced $(\mathrm{mL})$ per gram substrate utilized. The results shown in Table 1 and 2 demonstrated that by applying this method the hydrogen yield was enhanced and better than control. Beside that the $\mathrm{pH}$ changes (difference between initial and final $\mathrm{pH}$ ) was less as the reactor size increased. Enhancement of hydrogen production as shown in Fig. 1a and $\mathrm{b}$ indicated that by increasing the reactor size from $125-2 \mathrm{~mL}$, the hydrogen yield was enhanced from $269-448 \mathrm{~mL} \mathrm{~g}^{-1}$ glucose utilized respectively, this enhancement of bacterial production of hydrogen was due to that the reactor size offer more surface area and space for bacterial metabolites distribution and that was clear from the results shown in Fig. 2a and $b$ which indicated that by increasing the reactor size, that resulted to enhance the bacterial productivity of hydrogen from $70.8-91 \mathrm{mLL}^{-1} \mathrm{~h}^{-1}$ using $125 \mathrm{~mL}$ and $1 \mathrm{~L}$ reactor size respectively, then started to decrease for further increase in reactor size but the hydrogen yield was enhanced for further increase in reactor size and reached the maximum of $448 \mathrm{mLg}^{-1}$ using $2 \mathrm{~L}$ reactor size suggested that increasing the reactor size affect

Table 1: Results of changing reactor size on lag phase period (h), changes in $\mathrm{pH}$ and final Biomass concentration [Biomass] ( $\mathrm{g}$ $\left.\mathrm{L}^{-1}\right)$

\begin{tabular}{lllll}
\hline $\begin{array}{l}\text { Reactor } \\
\text { Size }(\mathrm{mL})\end{array}$ & $\begin{array}{l}\text { Lag phase } \\
\text { period }(\mathrm{h})\end{array}$ & $\begin{array}{l}\text { Change } \\
\text { in i } \mathrm{pH}\end{array}$ & Biomass & $\begin{array}{c}\text { Gas pressure } \\
(\mathrm{Kpa})\end{array}$ \\
\hline 125 & 11 & 2.3 & 1.03 & 12 \\
250 & 11 & 2.4 & 1.21 & 15 \\
500 & 10 & 2.55 & 1.38 & 18 \\
1000 & 9 & 2.44 & 1.53 & 21 \\
2000 & 8 & 2.41 & 1.68 & 23 \\
\hline
\end{tabular}


Am. J. Environ. Sci., 5 (1): 33-40, 2009

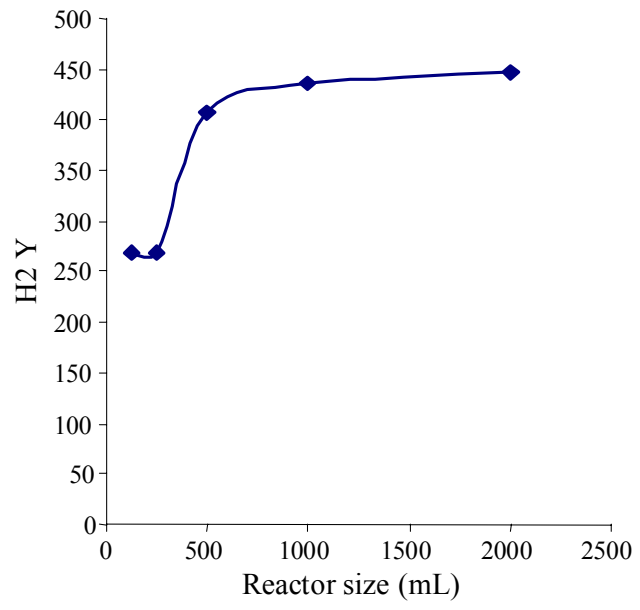

(a)

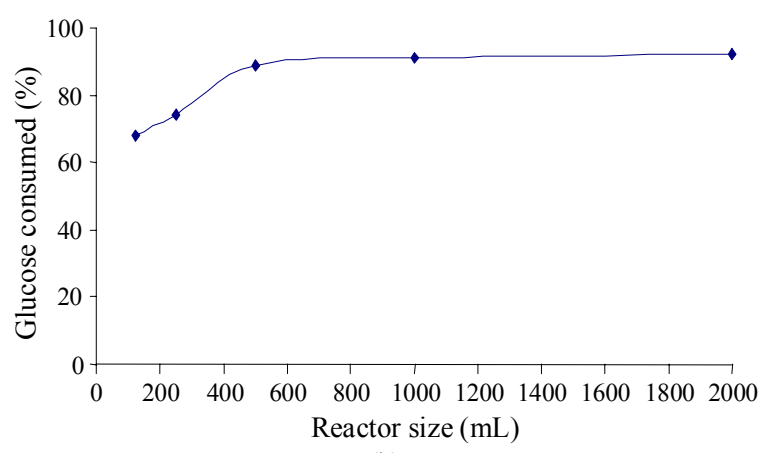

(b)

Fig. 1: Results of Reactor size effect on (a): $\mathrm{H}_{2}$ yield $\left(\mathrm{mL} \mathrm{g}^{-1}\right.$ glucose utilized); (b): Glucose consumed (\%): [Glucose]: $5 \mathrm{~g} \mathrm{~L}^{-1}$, inoculum size $10 \%(\mathrm{v} / \mathrm{v}) \mathrm{I} \mathrm{pH}$. 7.0. Temperature $30^{\circ} \mathrm{C}$

positively on the hydrogen yield but not for bacterial productivity of hydrogen.

For glucose consumption, the results shown in Fig. 1 suggested that increasing the reactor size hydrogen was mainly due to the enhancement of biomass concentration as shown in Fig. $2 b$ which reached the maximum of $1.68 \mathrm{~g} \mathrm{~L}^{-1}$ using $2 \mathrm{~L}$ reactor size. Above results suggested that as the increasing the reactor size will give chance to bacteria to meet the substrate easily and produce more gas and grow faster.

These results was agreed with the finding of Chung $^{[5]}$ they reported that hydrogen in fermentation medium would inhibits the growth of hydrogenproducing Clostridium cellobioparum, but not of Escherichia coli or Bacteroides ruminicola. They mentioned that the inhibition was reversible and when hydrogen was removed either by palladium black or by gassing out the tube, glucose utilization,

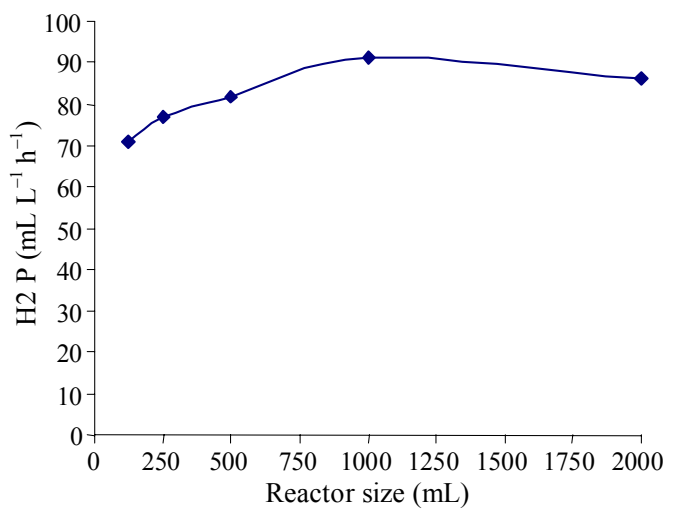

(a)

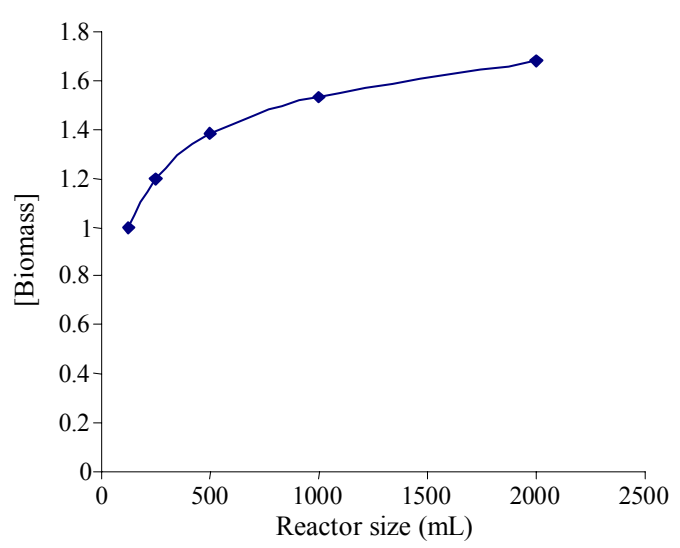

(b)

Fig. 2: Results of Reactor Size effect on (a): $\mathrm{H}_{2}$ Productivity $\left(\mathrm{mL} \mathrm{L}^{-1} \mathrm{~h}^{-1}\right)$; (b): [Biomass] $\left(\mathrm{gL}^{-1}\right)$, [Glucose]: $5 \mathrm{gL}^{-1}$, inoculum size $10 \%(\mathrm{v} / \mathrm{v}) \mathrm{I}$ pH. 7.0. Temperature $30^{\circ} \mathrm{C}$

biomass concentration and hydrogen production of C. cellobioparum were increased. Also they stated that removal of $\mathrm{H}_{2}$ by methanogenic bacteria (Methanobacterium ruminantium) favors the growth of C. cellobioparum and the Clostridium reaches a higher optical density and produces more $\mathrm{H}_{2}$ and a higher viable cell count. Concluded that presence of hydrogen gas in fermentation medium affect on the growth $C$. cellobioparum and its metabolism.

The results shown in Fig. 3 indicated that by increasing the reactor size that minimize the lag phase of bacterial growth due to more surface area for bacteria to meet available substrate and grow faster This implies that as the reactor size increased, the surface area increased, that would minimize the effect of the produced gas and the bacterial metabolites would distributes (gases and liquids), in a wider area that would minimize their effect on bacterial metabolism. 
Am. J. Environ. Sci., 5 (1): 33-40, 2009

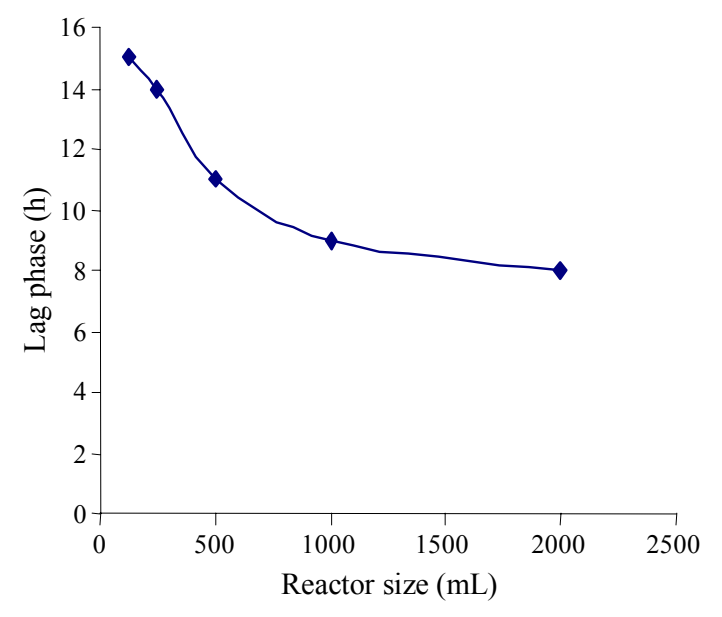

Fig. 3: Results of Reactor Size effect on Lag Phase period (h): [Glucose]: $5 \mathrm{~g} \mathrm{~L}^{-1}$, inoculum size $10 \%(\mathrm{v} / \mathrm{v}) \mathrm{I} \mathrm{pH}$. 7.0. Temperature $30^{\circ} \mathrm{C}$

From the above results it can confirm that increasing the reactor size would reduce the effect of produced gases (fermentation medium and headspace), which enhanced the bacterial growth which resulted to enhance the bacterial degradation of substrate and maximize hydrogen production.

A perusal of Table 1 results reveals that after hydrogen production stops the final gas pressure (production pressure) measured by water manometer, was increasing as the reactor size increased suggested that hydrogen production enhanced and that was due to the increase in the reactor size (void space and surface area). The hydrogen yield was enhanced from 269$448 \mathrm{~mL} \mathrm{~g}^{-1}$ glucose utilized, by using $125 \mathrm{~mL}$ and $2 \mathrm{~L}$, respectively, of reactor size $\left(2.15-3.6 \mathrm{~mol} \mathrm{H}_{2} \mathrm{moL}^{-1}\right.$ glucose utilized). Final pressure measured was increased from $12 \mathrm{Kpa}(\approx 90 \mathrm{mmHg}$ using $125 \mathrm{~mL}$ reactor size) to $23 \mathrm{Kpa}(\approx 173 \mathrm{mmHg}$ using $2 \mathrm{~L}$ reactor size). This finding agreed with the finding of Mandel et al. ${ }^{[19]}$ they reported that when the partial pressure of $\mathrm{H}_{2}$ was decreased by lowering the total pressure in the headspace of the reactor from 760-380 $\mathrm{mmHg}$, the molar yield increased from 1.9-3.9 mol $\mathrm{H}_{2} \mathrm{moL}^{-1}$ glucose supplied. Further decrease to $330 \mathrm{mmHg}$ lead to decrease the $\mathrm{H}_{2}$ yield from 3.9-2.9 $\mathrm{mol} \mathrm{H}_{2} \mathrm{moL}^{-1}$ glucose supplied.

$\mathrm{Y}_{\mathrm{P} / \mathrm{S}}^{1}\left(\mathrm{H}_{2} \mathrm{~mL} \mathrm{~g}^{-1}\right.$ glucose supplied $)\left(\mathrm{mL} \mathrm{g}^{-1)}\right), \mathrm{Y}_{\mathrm{P} / \mathrm{S}}^{2}$ ( $\left.\mathrm{mL} \mathrm{g}^{-1}\right)$ (Utilized): $\left(\mathrm{H}_{2} \mathrm{~mL} \mathrm{~g}^{-1}\right.$ glucose utilized), [Biomass] $\left(\mathrm{gL}^{-1}\right)$. Biomass production $\mathrm{g}$ per $\mathrm{L}$ culture, $\mathrm{Y}_{\mathrm{P} / \mathrm{X}}\left(\mathrm{mL} \mathrm{g}^{-1} \mathrm{~L}^{-1}\right):\left(\mathrm{H}_{2} \mathrm{~mL} \mathrm{~g}^{-1}\right.$ Biomass $\left.\mathrm{L}^{-1}\right), \mathrm{Y}_{\mathrm{X} / \mathrm{s}}$ : (Biomass production per $\mathrm{g}$ glucose supplied), $\mathrm{Y}_{\mathrm{H} 2 / \mathrm{s}}$ (conversion of $\mathrm{H}_{2}(\mathrm{~mL})$ to $\mathrm{H}_{2}(\mathrm{~g}) \mathrm{g}^{-1}$ glucose utilized) [Glucose]. $5 \mathrm{~g} \mathrm{~L}^{-1}$, inoculum size $10 \%(\mathrm{v} / \mathrm{v})$, I pH. 7.0 Temperature $30^{\circ} \mathrm{C}$.
Table 2: Results of the effect of changing reactor size on Hydrogen yield $\left(\mathrm{H}_{2} \mathrm{Y}\right), \mathrm{H}_{2} \mathrm{P}\left(\mathrm{mL} \mathrm{L}^{-1} \mathrm{~h}^{-1}\right)$

\begin{tabular}{llllllll}
\hline Reactor & Glucose & & & & & & \\
Size $(\mathrm{mL})$ & consumed $(\%)$ & $\mathrm{H}_{2} \mathrm{P}$ & $\mathrm{Y}_{\mathrm{P} / \mathrm{S}}^{1}$ & $\mathrm{Y}_{\mathrm{P} / \mathrm{S}}^{2}$ & $\mathrm{Y}_{\mathrm{P} / \mathrm{X}}$ & $\mathrm{Y}_{\mathrm{X} / \mathrm{S}}$ & $\mathrm{Y}_{\mathrm{H} 2 / \mathrm{s}}$ \\
\hline 125 & 68 & 70.8 & 183 & 269 & 261 & 0.20 & 0.020 \\
250 & 74 & 77.0 & 240 & 324 & 268 & 0.24 & 0.028 \\
500 & 89 & 81.6 & 364 & 408 & 296 & 0.28 & 0.036 \\
1000 & 91 & 91.0 & 397 & 436 & 285 & 0.30 & 0.038 \\
2000 & 92 & 86.0 & 412 & 448 & 273 & 0.34 & 0.040 \\
\hline
\end{tabular}

The results shown in Table 2 suggested that increasing the reactor size resulted in enhanced the hydrogen yield by $67 \%$ and that mainly due to the increased in biomass concentration by $63 \%$ which was enhanced by increasing the reactor size from $125 \mathrm{~mL}$ to $2 \mathrm{~L}$. According to obtained results different yields were obtained show that increasing the reactor size enhanced the biomass concentration as well as hydrogen production suggested that the as biomass concentration increased, the bacterial productivity of hydrogen was also increased but was restricted and start to decreased due to biomass byproducts inhibition whereas the biomass per substrate was increased suggested that reactor size play a major role in reduction of byproducts inhibition.

The results shown in Fig. 3 demonstrate that the highest $\mathrm{H}_{2}$ productivity was obtained was $91 \mathrm{~mL} \mathrm{~L}^{-1} \mathrm{~h}^{-1}$ when it is used $1 \mathrm{~L}$ reactor size and the final production gas pressure was $21 \mathrm{Kpa}$, then dropped to $86 \mathrm{~mL} \mathrm{~L}^{-1} \mathrm{~h}^{-1}$ and the pressure was $23 \mathrm{Kpa}$ using $2 \mathrm{~L}$ reactor size.

This finding was agreed with the observation of Yerushalmi et $a l .{ }^{[13]}$ they were using either pure hydrogen or helium to obtain reactor pressures ranging from 274-1479 Kpa, they found that under elevated partial pressures of hydrogen, butanol and ethanol yields were increased by an average of 18 and $13 \%$, respectively, whereas a much smaller increase was obtained when helium was used to pressurize the fermentation vessel. They suggested that the effect of hydrogen on the production of hydrogenase could be concentration dependent. These findings suggest that increase in the partial pressure of hydrogen in the medium result in a decrease of hydrogen production and affect inversely on bacterial metabolism.

The results shown in Fig. 1 and 2 show that $\mathrm{H}_{2}$ yield and $\mathrm{H}_{2} \mathrm{P}$ were dependent on the size of reactor. With increasing reactor size from $125 \mathrm{~mL}$ to $2 \mathrm{~L}$, both were increased till using $1 \mathrm{~L}$ reactor size but by using $2 \mathrm{~L}$, only $\mathrm{H}_{2}$ yield was increased but $\mathrm{H}_{2} \mathrm{P}$ was decreased.

The peak $\mathrm{H}_{2}$ yield values was $448 \mathrm{~mL} \mathrm{~g}^{-1} \mathrm{~g}$ glucose utilized using $2 \mathrm{~L}$ whereas, maximum $\mathrm{H}_{2} \mathrm{P}$ of $91 \mathrm{~mL} \mathrm{~L}^{-1} \mathrm{~h}^{-1}$ was obtained by using $1 \mathrm{~L}$ reactor size. 
Am. J. Environ. Sci., 5 (1): 33-40, 2009

Table 3: Comparison of maximum Hydrogen productivity reported in literature

\begin{tabular}{lllllll}
\hline Feedstock & $\mathrm{pH}$ & $\begin{array}{l}\text { Temperature } \\
\left({ }^{\circ} \mathrm{C}\right)\end{array}$ & $\begin{array}{l}\text { Seed sludge } \\
\left(\mathrm{mL} \mathrm{L}^{-1} \mathrm{~h}^{-1}\right)\end{array}$ & $\mathrm{H}_{2} \mathrm{Y}$ & $\mathrm{H}_{2} \mathrm{P}$ & Reference \\
\hline Sucrose & 6.8 & 35 & $\mathrm{SS}$ & - & $67-130$ & 16 \\
Starch & 5.2 & 37 & ADS & - & 20 & 14 \\
Wheat & 5.2 & 30,35 & ADS & 1.88 & 40 & 15 \\
Starch & 5.5 & 35 & SS & 1.5 & 450 & 16 \\
POME & 5.5 & 60 & POME S & & 954 & 17 \\
Glucose & 7.0 & 30 & C. acetobutylicum & 3.3 & & This study \\
& & & NCIMB13357 & & & \\
\hline
\end{tabular}

SS: Sewage Sludge; AS: Acclimated Sludge; ADS: Anaerobically Digested Sludge, POME: Palm Oil Mill Effluent. $\mathrm{HY}_{\mathrm{P} / \mathrm{S}}\left(\mathrm{H}_{2} \mathrm{~mol} \mathrm{moL}^{-1}\right.$ glucose supplied)

Moreover, the peak $\mathrm{H}_{2} \mathrm{P}$ reached $91 \mathrm{~mL} \mathrm{~L}^{-1} \mathrm{~h}^{-1}$ which was higher of $20 \mathrm{~mL} \mathrm{~L}^{-1} \mathrm{~h}^{-1}$ obtained by Lay ${ }^{[14]}$ and more than obtained by Hussy et al. ${ }^{[15]}$ they reported that the maximum productivity by mixed culture was $40 \mathrm{~mL} \mathrm{~L}^{-1} \mathrm{~h}^{-1}$ whereas was lower than reported values of $130-454 \mathrm{~mL} \mathrm{~L}^{-1} \mathrm{~h}^{-1}$ (Table 3). This variation in the productivity seems to suggest that mixed culture is better for complex material than pure culture due to variation of enzymes involved for complex carbohydrates degradation Obtained data shown in Table 1 and 2 were used to calculate different yields like $\mathrm{Y}_{\mathrm{P} / \mathrm{X}}\left(\mathrm{mL} \mathrm{g}^{-1} \mathrm{~L}^{-1}\right):\left(\mathrm{H}_{2} \mathrm{~mL} \mathrm{~g}^{-1}\right.$ Biomass $\left.\mathrm{L}^{-1}\right), \mathrm{Y}_{\mathrm{X} / \mathrm{S}}$ : (Biomass production per g glucose supplied) and $\mathrm{Y}_{\mathrm{H} 2 / \mathrm{s}}$ (conversion of $\mathrm{H}_{2}(\mathrm{~mL})$ to $\mathrm{H}_{2}(\mathrm{~g})$ per $\mathrm{g}$ glucose utilized). These results showed that increasing the reactor size was enhancing the biomass concentration and that was the source for enhancement of the hydrogen productivity and hydrogen yield.

\section{DISCUSSION}

The sharp increase of yield has certain implications. Firstly, the increase of reactor size might have facilitated the equilibrium of the desired reaction thereby minimizing the likelihood of any sort of inhibition by unwanted solventogenic pathways. Secondly, the partial pressure of produced gases by increasing the surface area and void space of the reactor inhibits the consumption of $\mathrm{H}_{2}$ leading to the production of reduced by-products such as ethanol and/or organic $\operatorname{acids}^{[6]}$. Since alcohol production involves the consumption of $\mathrm{H}_{2}$ in the form of reducing equivalents such as $\mathrm{NADH}$, it is inevitable that fermentation conditions that favor the metabolism of sugar to alcohols reduce $\mathrm{H}_{2}$ production. Further, Oh et $a l^{[7]}$ claimed that the stripping of gas favors increased dissolution driving force by increasing the pressure difference between the liquid phase and the gas phase in the headspace of the reactor. This result in increased the rate of $\mathrm{H}_{2}$ production in the system suggested to us that the pressure that may affect on bacterial metabolism or growth is higher than what was measured in this study and could be minimize by increasing the reactor size. Experimental results indicated that although the consumption of substrate gradually increased with increasing the reactor size Table 2, it was not proportional with $\mathrm{H}_{2}$ production. These imply that regulation of metabolic pathway is rather more important for increased $\mathrm{H}_{2}$ production. Consistent increase in $\mathrm{H}_{2}$ yield from glucose by increasing the reactor size focuses the requirement to optimize the same for maximum $\mathrm{H}_{2}$ yield.

Additional significant feature of increasing the size of the reactor was the decrease of initiation time for gas production. This can be attributed to the decrease of gas solubility in the production medium at low pressure. At low pressure, the dissolved gases, initially present in the production media might tend to escape to the headspace of the reaction vessel and be replaced by nitrogen. Once production of gas starts, it escapes from liquid phase to the gas phase. Under these conditions, the production media could be considered to remain as a homogeneous liquid system rather than heterogeneous gas-liquid system. This homogeneity of the medium might have facilitated the substrate utilization by microorganisms effectively. The decrease in batch time due to increasing reactor size might be because the dissolved gases during production have not hindered the utilization of substrate, that will enhanced the stripping of gas.

In hydrogen production, conditions are sought maximizing acetic acid production as this gives the maximum hydrogen yield (Eq. 1). The concept of fermentative hydrogen production is contrary to the more well studied solvent producing acetone-butanol fermentation in which the production of molecular hydrogen and acetate is unnecessary and decreases solvent recovery. End products such as $\mathrm{H}_{2}, \mathrm{CO}_{2}$, acetate and butyrate are the result of side reactions in the acetone butanol fermentation process ${ }^{[8]}$. Thus, a study of the conditions detrimental to solvent production will give information on those conditions favoring hydrogen and acetate production. 
Am. J. Environ. Sci., 5 (1): 33-40, 2009

Table 4: Comparative studies on the $\mathrm{H}_{2}$ yields using different microbial strains and different process

\begin{tabular}{lllll}
\hline Organisms & Substrates & Process & $\mathrm{H}_{2} \mathrm{Y}$ & Reference \\
\hline $\begin{array}{l}\text { C.acetobutylicum NCIMB13357 } \\
\text { Rhodopseudomonas palustris P4 }\end{array}$ & glucose & Batch, Increasing reactor size. & 3.3 & This study \\
$\begin{array}{l}\text { Enterobacter aerogens } \\
\text { Enterobacter cloacae /Emphasis }>\end{array}$ & glucose & Batch, with intermittent purging of Ar & 2.8 & 6 \\
IIT BT 08 & Ar sparging, batch & 1.6 & 20 \\
Citrobacter sp. Y19 & glucose & Continuous (Immobilized bioreactor & 2.3 & 21 \\
$\begin{array}{l}\text { C.thermolacticum } \\
\text { Enterobacter cloacae DM11 }\end{array}$ & glucose & Batch Ar sparging & 2.5 & 7 \\
& lactose & Batch (using KOH as scavenger) & $2.1-3.0$ & 22 \\
& glucose & Batch at operating pressure 380 mm of Hg & 3.9 & 19 \\
\hline
\end{tabular}

Glucose is the fundamental resource for hydrogen production. Glucose is fermented via the EMP pathway to pyruvate. Pyruvate oxidation to acetyl coenzyme A requires ferredoxin $(\mathrm{Fd})$ reduction. Reduced $\mathrm{Fd}$ is oxidized by hydrogenase, which generates $\mathrm{Fd}$ and releases electrons as molecular hydrogen. Therefore, hydrogen production is the means by which bacteria lose excess electrons. The reaction is reversible and depends on hydrogen partial pressure $\left(\mathrm{pH}_{2}\right)$, suggesting that hydrogen yield is significantly influenced by $\mathrm{pH}_{2}$.

The effects of hydrogen on the metabolism and the fermentative pattern of the anaerobic bacteria have been demonstrated in previous studies. Clostridium cellobioparum produces more hydrogen when it is removed by hydrogen-consuming methanogens ${ }^{[5]}$. The quantitative composition of the fermentation products depends on the $\mathrm{pH}_{2}$. Van Andel et al ${ }^{[9]}$ demonstrated that sparging a pure culture of Clostridium butyricum with nitrogen increased the rate of acetate production both absolutely and relative to the rate of butyrate production. Lamed et al. ${ }^{[10]}$ reported that the production of acetate and hydrogen by Clostridium thermocellum has been considered an obstacle to the use of this organism in ethanol production and stirring the cultures favored hydrogen and acetate production, attributed that to accumulation of hydrogen at supersaturated concentrations in unstirred conditions inhibiting acetate production.

On the contrary, of hydrogen production, Wood and Jones ${ }^{[11]}$ reported that when $\mathrm{AB}$ fermentation was run under a pressure of $2000 \mathrm{~K}$ pa.s, the yield of butanol was increased and the yield of butyrate decreased, these observation means under high pressure the acid and hydrogen production was decreased. Another reports by ${ }^{[11]}$ they reported that by increasing the headspace pressure from $100-250 \mathrm{Kpa}$ the yield of butanol and ethanol, but not acetone, could be increased. Regarding to above findings ${ }^{[12]}$ observed that the pressure within the reactor affected the level of dissolved hydrogen gas in the fermentation medium, which in turn affected solvent production. All of these reports focused on how the pressure inside the reactor vessel affected on bacterial metabolism and force the bacteria to shift its metabolism from phase to phase.

According to Wooshin et al. ${ }^{[18]}$, each $125 \mathrm{~mL} \mathrm{H}_{2} \approx$ 1 mole $\mathrm{H}_{2}$. Following this data, the maximum hydrogen yield obtained by increasing the reactor size using $2 \mathrm{~L}$ was of $3.3 \mathrm{molH}_{2} \mathrm{moL}^{-1}$ glucose supplied $\left(412 \mathrm{~mL} \mathrm{~g}^{-1}\right.$ g glucose supplied) and this yield was lower than the reported yield of $3.9 \mathrm{molH}_{2} \mathrm{moL}^{-1}$ glucose supplied was reported by ${ }^{[19]}$ by controlling the operating pressure and higher than $2.8 \mathrm{molH}_{2} \mathrm{moL}^{-1}$ glucose supplied whereas higher than the hydrogen yield reported by ${ }^{[6]}$ by sparging using $\mathrm{Ar}$ and other methods employed were reported in Table 4. Hydrogen yield: $\left(\mathrm{H}_{2} \mathrm{Y}\right):\left(\mathrm{mL} \mathrm{g}^{-1}\right.$ glucose supplied)

Wood and Jones ${ }^{[11]}$ reported that, under conditions which resulted in a high concentration of hydrogen, the $\mathrm{H}^{+} / \mathrm{H}_{2}$ redox potential is lowered and the flow of electrons from reduced ferredoxin to molecular hydrogen via the hydrogenase system is inhibited. Under these conditions the electron flow would be shifted to the generation of NAD (P)H via the action of the appropriate ferredoxin oxidoreductase, resulting in an increase in the production of butanol and ethanol. Above suggestion showed how the pressure of produced gas affects on the bacterial metabolites and the effect on the enzyme level.

Concluded that the bacteria have the ability to adapt with the new environment due to its metabolites effect and that all connected with the bacterial genome. Wood and Jones ${ }^{[11]}$ reported that the hydrogenase activity in whole cells from acid-producing cultures maintained at $\mathrm{pH} 5.8$, it about 2.2 times higher than that measured in solvent-producing cultures maintained at $\mathrm{pH}$ 4.5. George and Chen ${ }^{[24]}$ they used C. beijerinckii also reported that extracts from solvent producing cells exhibited lower levels of hydrogenase activity than those from acid-producing cells. Both suggestion demonstrated that hydrogen evolution depend on the activity of hydrogenase enzyme.

In an attempt to determine weather the lower hydrogenase activities measured in solvent-producing cells due to inhibition by low $\mathrm{pH}$ or the accumulation of acid end products, Kim et al. ${ }^{[8]}$ they reported that 
neither $\mathrm{pH}$ nor fatty acid concentration affected hydrogenase activity and they concluded that the decrease in hydrogen production in the solventogenic phase was due to the regulation of hydrogenase production rather than inhibition of enzyme activity. Wood and Jones ${ }^{[11]}$ reported that hydrogenase activity was optimal at a $\mathrm{pH}$ of 8.5 and no activity could be detected below $\mathrm{pH}$ 6.0. Suggested that the hydrogenase from solvent producing cells grown at $\mathrm{pH} 4.5$ was present in an inactive form but was activated after a lag period under the conditions they used in the assay.

\section{CONCLUSION}

In this study, the effect of reactor size was studied on $\mathrm{H}_{2}$ production by C. acetobutylicum NCIMB13357. Increasing reactor size, resulted to enhance the bacterial productivity, hydrogen yield and bacterial growth Maximum hydrogen productivity was enhanced from 71-91 $\mathrm{mL} \mathrm{L}^{-1} \mathrm{~h}^{-1}$ whereas hydrogen yield enhanced from 269 to $448 \mathrm{~mL} \mathrm{~g}^{-1}$ glucose utilized. Biomass concentration was enhanced with reactor size and reached the maximum of $1.68 \mathrm{~g} \mathrm{~L}^{-1}$. Further research should be done using bigger reactor size or to study at what pressure the yield value of hydrogen will inversely affected.

\section{ACKNOWLEDGMENT}

The researcher would like the thank Universiti Kebangsaan Malaysia for financial assistance under grant No UKM-OUP-BTK-14/2007.

\section{REFERENCES}

1. Fabiano, B. and P. Perego, 2002. Thermodynamic study and optimization of hydrogen production by Enterobacter aerogenes. Int. J. Hydrogen Energ., 27: $\quad 149-156 . \quad$ DOI: $10.1016 / \mathrm{S} 0360-$ 3199(01)00102-1.

2. Levin, D., L. Pitt and M. Love, 2004. Biohydrogen production: Prospects and limitations to practical application. Int. J. Hydrogen Energy, 29: 173-185. DOI: 10.1016/S0360-3199(03)00094-6.

3. Morimoto, M., M. Atsuko, A.A.Y. Atif, M.A. Ngan, A. Fakhrul-Razi, S.E. Iyuke and A.M. Bakir, 2004. Biological production of hydrogen from glucose by natural anaerobic microflora. Int. J. Hydrogen Energ., 29: 709-713. DOI: 10.1016/j.ijhydene.2003.09.009.
4. Miller, G.L., 1959. Use of Dinitrosalicyclic acid reagent for determination of reducing sugar. Anal. Chem., 31: 426-429. http://pubs.acs.org/ doi/abs/10.1021/ac60147a030.

5. Chung, K.T., 1976. Inhibitory Effects of $\mathrm{H}_{2}$ on Growth of Clostridium cellobioparum. Applied Environ. Microbiol., 31: 342-348. http://www. ncbi.nlm.nih.gov/pubmed/779644.

6. Oh, Y.K., E.H. Seol, L.E. Yeol and S. Park, 2002. Fermentative hydrogen production by a new chemolithotrophic bacterium Rhodopseudomonas palustris P4. Int. J. Hydrogen Energ., 27: $\quad 1373-1379$. DOI: $10.1016 / \mathrm{S} 0360-$ 3199(02)00100-3.

7. Oh, Y.K., E.H. Seol, J.R. Kim and S. Park, 2003. Fermentative biohydrogen production by a new chemoheterotrophic bacterium Citrobacter sp. Y19. Int. J. Hydrogen Energ., 28: 1353-1359. DOI: 10.1016/S0360-3199(03)00024-7.

8. Kim, B.H, P. Bellows, R. Datta and J.G. Zeikus, 1984. Control of carbon and electron flow in Clostridium acetobutylicum fermentations: Utilization of carbon monoxide to inhibit hydrogen production and to enhance butanol yields. Applied Environ. Microbiol., 48:764-770. http://www.ncbi. nlm.nih.gov/pubmed/16346643.

9. Van Andel, J.G., G.R. Zoutberg, P.M. Crabbendam and A.M. Breure, 1985 Glucose fermentation by Clostridium butyricum grown under a self generated gas atmosphere in chemostat culture. Applied Microbiol. Biotechnol., 23: 21-26. DOI: 10.1007/BF02660113.

10. Lamed, J., J.H. Lobos and T.M. Su, 1988. Effect of stirring and hydrogen on fermentation products of Clostridium thermocellum. Appied Environ. Microbial., 54: 1216-1221. http://cat.inist.fr/ ?aModele $=$ afficheN\&cpsidt $=7730383$.

11. Woods, D.R. and D.T. Jones, 1986. Physiological responses of Bacteroides and Clostridium strains to environmental stress factors. Adv. Microbial Physiol., 27: 1-64. http://www.ncbi.nlm. nih.gov/pubmed/3544734.

12. Doremus, M.G., J.C. Linden and A.R. Moreira, 1985. Agitation and pressure effect on acetone butanol fermentation. Biotechnol. Bioeng., 27: $\quad 852-860 . \quad$ http://www.ncbi. nlm.nih.gov/pubmed/18553746.

13. Yerushalmi, L., B. Volesky and T. Szczesny, 1985. Effect of increased hydrogen partial pressure on the acetone-butanol fermentation by Clostridium acetobutylicum. Applied Microbiol. Biotechnol., 22: 103-107. DOI/: 10.1007/BF00250028. 
14. Lay, J.J., 2000. Modelling and optimization of anaerobic digested sludge converting starch to hydrogen. Biotechnol. Bioeng., 68: 269-278. DOI: 10.1002/(SICI)1097-0290(20000505).

15. Hussy, I., F.R. Hawkes, R. Dinsdale and D.L. Hawkes, 2003. Continuous fermentative hydrogen production from a wheat starch coproduct by mixed microflora. Biotechnol. Bioeng., 84: 619-626. http://www.ncbi.nlm.nih. gov/pubmed/14595774.

16. Lin, C.Y., C.C. Chang and C.H. Hung, 2008. Fermentative hydrogen production from starch using natural mixed cultures. Int. J. Hydrogen Energ., 33: 2445-2453. DOI: 10.1016/j.ijhydene.2008.02.069.

17. Atif, A.A.Y., A. Fakhrul-Razi, M.A. Ngan, M. Morimoto, S.E. Iyuke and N.T. Veziroglu, 2005. Fed batch production of hydrogen from palm oil mill effluent using anaerobic microflora. Int. J. Hydrogen Energ., 30: 1393-1397. DOI: 10.1016/j.ijhydene.2004.10.002.

18. Wooshin, P., H.H. Seung, O.H. Sang-Eun, B.E. Logan and I.S. Kim, 2005. Removal of headspace $\mathrm{CO}_{2}$ increases biological hydrogen production. Environ. Sci. Technol., 39: 4416-4420. http://pubs.acs.org/doi/abs/10.1021/es048569d.
19. Mandel, B., K. Nath and D. Das, 2006. Improvement of biohydrogen production under decreased partial pressure of $\mathrm{H} 2$ by Enterobacter cloacae. Biotechnol. Lett., 28: 831-835. DOI: 10.1007/s10529-006-9008-8.

20. Tanisho, S., M. Kuromoto and N. Kadokura, 1998. Effect of $\mathrm{CO}_{2}$ removal on hydrogen production by fermentation. Int. J. Hydrogen Energ., 23: 559-563. DOI: 10.1016/S03603199(97)00117-1.

21. Kumar, N. and D. Das, 2000. Enhancement of hydrogen production by Enterobacter cloacae IITBT 08. Process. Biochem., 35: 589-593. DOI: 10.1016/S0032-9592(99)00109-0.

22. Collect, C., N. Adler, J.P. Schwitzguebel and P. Peringer, 2004. Hydrogen production by clostridium thermolacticum during continuous fermentation of lactose. Int. J. Hydrogen Energ., 29: 1479-1485. DOI: 10.1016/J.IJHYDENE.2004.02.009.

23. George, H.A. and J.S. Chen, 1983. Acidic conditions are not obligatory for onset of butanol formation by Clostridium beijerinckii synonym, C. butylicum. Applied Environ. Microbiol., 46: 321-327. http://www.pubmedcentral. nih.gov/articlerender.fcgi? artid=239380. 